\title{
The Public University in Brazil Is Revisiting Its Social Commitment to Establish a School-Based Sex Education Program
}

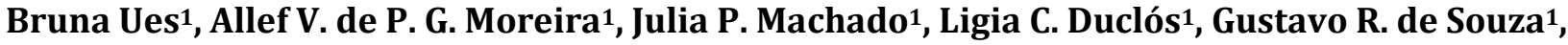 \\ Allydson Simes ${ }^{1}$, Roxana Knobel ${ }^{2}$, Jaime Cofre ${ }^{3 *}$
}

${ }^{1}$ UFSC, Florianópolis, Brazil

${ }^{2}$ Department of Obstetrics \& Gynecology, Universidade Federal de Santa Catarina, Florianópolis, Brazil

${ }^{3}$ Sexual and Reproductive Health Program, Universidade Federal de Santa Catarina, Florianópolis, Brazil

Email:*jaime.cofre@ufsc.br

How to cite this paper: Ues, B., de P. G. Moreira, A.V., Machado, J.P., Duclós, L.C., de Souza, G.R., Simes, A., Knobel, R. and Cofre, J. (2016) The Public University in Brazil Is Revisiting Its Social Commitment to Establish a School-Based Sex Education Program. Open Journal of Social Sciences, 4, 124-139.

http://dx.doi.org/10.4236/jss.2016.49012

Received: July 11, 2016

Accepted: September 19, 2016

Published: September 22, 2016

Copyright $\odot 2016$ by authors and Scientific Research Publishing Inc. This work is licensed under the Creative Commons Attribution International License (CC BY 4.0).

http://creativecommons.org/licenses/by/4.0/

\begin{abstract}
The sexual and reproductive health program, in Florianópolis/SC, promoted workshops, mounted and performed by medical students, in public elementary schools. After that, it was possible to investigate the students' opinion with a transverse quantitative study. 333 school children aged from 11 to 16 and enrolled between 5th and 9th grades answered the questionnaire. In the sample, $15.9 \%$ had initiated sexual activity, and $38.8 \%$ of them did not use condoms every time. The young people who have not started sexual activities talk about sexuality with their parents in greater proportion than those who have already started (significant difference). The students' evaluation about the project was positive. It is expected to raise interest in new strategies for sex education permanently in public elementary schools, with the support of higher education institutions and strengthening the participation of parents and caretakers, in the process.
\end{abstract}

\section{Keywords}

School-Based Sex Education, Multidisciplinary Workshops, Medicine Faculty

\section{Introduction}

In Brazil, the formal sexual health education for adolescents has been influenced by changing government policies and public opinion [1]. In the late 1980s, the majority of Brazilian sex education initiatives dealt with sexuality as a positive and healthy experience, in many cases, as a partnership between non-governmental organizations (NGOs) and government agencies (public sector) [2]-[4]. Since 1990, when the government ap- 
proved a Statute for Children and Adolescents [5], the country has been struggling to deal with the special needs of this segment of the population. While some programs have been implemented and there is some notable change of attitudes and behaviors among adolescents, both the government and the NGOs agree that there is still much to be accomplished [2] [6].

Some studies of the World Health Organization show that $22 \%$ of teenagers initiate the sexual activity at the age of 15 [7], and the National Research of the Student's Health shows that $30.5 \%$ of them, in the ninth grade, already had sexual intercourse [4] [8]. The early sexual initiation is associated with the non-use or inappropriate use of condoms and its consequences [7]-[9].

Only in 1998, however, sex education was officially included, in the Brazilian national school curriculum [3], as a cross-cutting theme that should be linked to the contents of each school subject, in the primary and high schools. Unfortunately, it was not accompanied by a parallel process of preparing teachers, and there were no significant changes made in the syllabus of the university education courses to ensure that new teachers should be prepared to teach sexual education in order to cover a wide range of issues, among them, self-esteem, pubertal changes, as well as responsible sexual decision-making and sexual initiation [2] [3].

Initiatives addressing theoretical and methodological issues have been developed to assist teachers in dealing with various themes in sex education within the sphere of science and this approach is still deeply rooted. The biomedical discourse is the most valued and widespread in the schools in general [3] [10]-[13]. Obviously these topics are favorable for discussion in science classes and constitute an important dimension to be addressed in sex education, especially in a context like that of Florianopolis, where the incidence of HIV and STDs infection are matters of concern [3] [8] [14].

Since the year 2000, the state of Santa Catarina (in the south region of Brazil) is among the five states with the highest rates of infection with HIV and, in 2009, the southern region stood out with the highest rate, in Brazil, with 12.6/100,000 inhabitants between 13 and 24 years. Of the total births attended by the Public Health System (SUS), in 2007, 55\% were adolescents and young people between 10 and 24 years [8] [14].

Nowadays, at the schools, the guidance of the national curricular parameters about sexual orientation has to be treated as a cross-cutting topic, in the curricula, from the sixth grade [3]. Through the discussion on human reproduction in the subject of Natural Sciences, the children get information or concepts related to the anatomy and physiology of the human body. However, this approach does not usually cover the anxieties and curiosities of the children as it only focuses on the biological body, and it does not include the cultural, social and affective dimensions contained in the same body [8] [10] [12].

On the other hand, the National Curriculum Guidelines of the medical undergraduate course: 1) Point to the need for training professionals able to integrate the biological, psychological, social and environmental dimensions in the health-disease process, 
also for working in multidisciplinary teams in order to produce health, and getting general, humanist, critical and reflective training. 2) Therefore, the curriculum content should be guided by methodologies that encourage the active participation of the student, in the construction of knowledge, and linking the medical and academic training to the health and social needs [15]. 3) The main objective would be to integrate teaching and service. Then, it is necessary to move the current training axis, which is focused on the individual assistance offered in specialized units, into a process directed to the social, economic and cultural needs of the population [15]-[19].

Health Promotion is the empowerment of people and communities in order to modify health determinants for the benefit of their own life quality [20]. For the PAHO/WHO, the definition is "the sum of the population actions, health services, health authorities and other social and productive sectors aimed at the development of better conditions for individual and collective health" [7].

Several studies showed that the promotion actions to the sexual health of adolescents may have a positive influence on their health [9] [21]-[27]. In Nigeria, where the high school students are beginning their sexual life early and having a high risk of HIV contamination, health education initiatives were implemented. Thus, it was possible to observe a decrease in the average number of sexual partners of the participants, a consistent increase in the use of a condom in the last sexual intercourse [21]. In Londrina, in the post-workshops of prevention assessment, an increase of knowledge surpassed $55.8 \%[22]$.

At the medical school, the student has little contact with the subject and health promotion activities [28] [29]. There is a need to address the topic of sexuality and reproductive rights at the faculty of medicine, in its multiple aspects, in order to train professionals who know how to deal with their own sexuality. Thus, they need to be trained not only to guide, but also to educate, treat diseases, promote actions and develop programs like managers and consultants [16] [18] [19] [28] [30].

Therefore, it appears to be training and information inefficiency on specific aspects related to a healthy and safe sexuality both at the school and in the course of medicine [7] [8] [28] [29]. A reliable reflection of this context of misinformation among children, adolescents, and young people is the growing number of them infected with HIV, setting a new reality in the elementary schools and civil society needs to understand. Then, it is possible to show that among adolescents who participated in the study and already began their sexual life, most of them are in the age group of 11 to 12 years. There is a revealing aspect of how the lack or misuse of information may be leading teens to have risky behaviors from their sex life. On the other hand, it shows the university importance to developing health prevention strategies with a particular focus on children and adolescents based on dialogues and linked to the curriculum, in the most friendly and safe environment that adolescents can have: the school. In the paper, the authors also present evidence that the conversation with an adult, parent or guardian might delay the sexual initiation and ensure safer adolescents' behaviors when deciding to have sex. Therefore, the sex program created by the public university of Brazil will establish con- 
tinuous and permanent links with youngsters to ensure the university's role committed to the social reality. The purpose of this article is to describe the results of sexual and reproductive health program at the public schools of the city of Florianópolis, the characteristics of the students attended and their views about the project and the involvement of medical students in their schools.

\section{Materials and Method}

\subsection{Students}

This is a cross-sectional and quantitative study performed through questionnaires administered to the students, after their participation in workshops on self-care and sexuality. The research subjects were students between 11 and 16 years old, from the fifth to ninth grades of municipal public schools that were previously selected.

The inclusion criteria were: being a student regularly enrolled in the school grades involved and the schools participating in the project, and wishing to fulfill the questionnaire. The exclusion criterion was the lack of signature by their parents or legal guardians of the Free and informed consent term for the students fill out the questionnaires. The information was obtained through an anonymous and self-administered questionnaire given to the participants, in the school class period. The questionnaires were delivered to the students and collected by the elementary school teachers along with the medical students.

The analyzed variables were age, gender, school grade, if the student has children, if the student already had sexual activity, age of the first sexual intercourse, condom use frequency. Also, with whom the student has conversations or asks questions about sexuality (parents or legal guardians, health professionals, school teachers, professors of the project, friends/colleagues, nobody). Their opinions on the workshops taught (self-esteem and respect for the body, knowledge and puberty changes, respect for colleagues and other people's limits, sexually transmitted diseases, contraception methods). And finally, if they liked the medical students' work and they would like to continue the following year.

In order to assess the students' opinions on each workshop, they used to fill a Likert type scale with the options for the current analysis. It was considered as favorable opinions to those who responded "Excellent" and "Very good," and it was considered as unfavorable opinions to those who responded "Good" and "Bad." The students" opinions (favorable and unfavorable) were considered as an independent variable in order to examine if there were differences among the opinions relating to the workshops depending on the students' characteristics. It was also tested the following variables: initiated sexual activity, gender, conversations with parents/legal guardians and age as dependents.

The teachers or directors who were responsible for each one of the eight schools involved also answered a questionnaire. Since there were only eight questionnaires, they were analyzed in a descriptive way. The questionnaires were entered and analyzed in the program Epi INnfo 7. It was considered a significance level of 5\%. 


\subsection{Schools and Medicine Students}

The schools were selected through technical criteria by the Coordination of the School Health Program (Government's Program: Programa Saúde na Escola) of the municipality that included the vulnerability of communities and demands required by the schools themselves. The 18 medicine students from the sophomore and junior years who participated in the program were properly selected. They received specific training and university scholarships.

\subsection{Workshops}

Initially, there was an identification of the information needs relating to the adolescents and a collection of specific local problems [31]. Since sexuality is a cross-cutting topic that can be approached by different ways, in many compulsory subjects of the school curriculum, the workshops directly related to it were conducted in Science, Mathematics, Portuguese, History, Arts and Physical Education classes [30] [32]. They aimed to address various issues such as self-esteem, pubertal changes, as well as sexual initiation. All the activities were engaged and articulated with the teachers' annual planning.

The proposed workshops were: Self-esteem and respect for the body (it was attempted to value and respect the own body and the classmate body); Self-knowledge and pubertal changes (aimed to present anatomical and physiological aspects involved in the process of puberty). Respect for the colleagues and other persons' limits (it was possible to work with boundaries, desires, group and individual behavior and psychological aspects associated with puberty). The prevention of sexually transmitted diseases (discussion about major diseases, transmission means and hygiene); the contraceptive methods and uses (discussion about family planning). All the workshops tried to utilize active learning-teaching methods, with the students' participation during the process.

\subsection{Ethics}

The project was approved by the Committee of Ethics in Research with Human Beings of UFSC, under the number 15017813.0.0000.0121. The confidentiality about the information source was maintained. The questionnaires were only answered by the students who had informed consent document signed by their parents or legal guardians.

\section{Results}

It was possible to perform 40 workshops in eight schools, involving 18 medical students, five university professors, 15 teachers from the public elementary school of Florianópolis and 1115 elementary school students from the public schools. All the students that participated of the project activities students were invited to participate in the study, at all the participating schools; however, only those who brought the informed consent signed by their parents or legal guardians were able to complete the questionnaire. 333 students answered the questionnaires, and all delivered questionnaires were considered for analysis.

The main characteristics of the group (students who responded to the question- 
naires) are shown in Table 1 . The studied population is constituted predominantly by teenagers between 13 and 14 years, and enrolled between the fifth and ninth grades of the public elementary schools, in Florianopolis. Among the adolescents who participated, it is noteworthy that the number of those who have already started a sexual life is higher among the students of 12 years or less, and almost $30 \%$ of the total does not use or occasionally uses condoms. In a total of 333 respondents, 6 students (4.09\%) confirmed to have children.

Table 2 shows the distribution of students who already started or not their sexual activity, and their preferences to speak about sexuality. There was a statistical significance on the students' responses about the beginning of their sexual activities and the conversations with adults or parents about sexuality. Of those who have already initiated sexual activities, 50\% speak with an adult and 34\% speak with their parents. Among those who did not start sexual activities, 66\% speak with an adult and more than 50\% have conversations with their parents.

Table 1. Characteristics of the students interviewed.

\begin{tabular}{|c|c|c|}
\hline & $\mathrm{n}$ & $\%$ \\
\hline \multicolumn{3}{|l|}{ Age } \\
\hline 12 years or less & 73 & 21.92 \\
\hline $13-14$ years & 198 & 59.46 \\
\hline 15 years or more & 57 & 17.1 \\
\hline Ignored/ no answer & 5 & 1.5 \\
\hline \multicolumn{3}{|l|}{ Gender } \\
\hline Feminine & 183 & 54.95 \\
\hline Masculine & 142 & 42.64 \\
\hline Ignored/no answer & 8 & 2.4 \\
\hline \multicolumn{3}{|l|}{ School grade } \\
\hline $5^{\circ}-6^{\circ}$ & 148 & 44.44 \\
\hline $7^{\circ}, 8^{a}$ and $9^{a}$ & 179 & 53.75 \\
\hline Ignored/no answer & 8 & 2.4 \\
\hline \multicolumn{3}{|c|}{ First sexual intercourse age $e^{\star}$} \\
\hline 12 years or less & 29 & 8.71 \\
\hline $13-14$ years & 15 & 4.50 \\
\hline 15 years or more & 9 & 2.7 \\
\hline Did not start & 262 & 83.17 \\
\hline Ignored/ no answer & 18 & 5.4 \\
\hline \multicolumn{3}{|l|}{ Use of condom ${ }^{\star}$} \\
\hline Always & 41 & 61.19 \\
\hline Often & 6 & 8.96 \\
\hline Ocassionally/Never & 20 & 29.85 \\
\hline
\end{tabular}

${ }^{*} 71$ students reported that already had sexual activity -67 students responded on the condom use, and 53 students responded about the age of their first sexual intercourse. 
Table 2. Distribution of students in relation to the beginning of sexual activity and according to the person they refer to talk to/ask questions about sexuality.

\begin{tabular}{|c|c|c|c|c|c|}
\hline & \multicolumn{2}{|c|}{$\begin{array}{l}\text { Initiated Sexual Activity } \\
\qquad(\mathrm{n}=71)\end{array}$} & \multicolumn{2}{|c|}{$\begin{array}{c}\text { Did not Initiate Sexual } \\
\text { Activity } \\
(\mathrm{n}=256)^{*}\end{array}$} & \multirow[t]{2}{*}{$\mathrm{p}$} \\
\hline & $\mathrm{n}$ & $\%$ & $\mathrm{n}$ & $\%$ & \\
\hline Do not speak with anyone & 17 & 23.94 & 59 & 23.05 & 0.43 \\
\hline Speak with an adult & 35 & 49.3 & 169 & 66.02 & 0.005 \\
\hline $\begin{array}{c}\text { Speak with } \\
\text { parents/responsible adults }\end{array}$ & 24 & 33.8 & 144 & 56.25 & 0.001 \\
\hline Speak with teachers & 4 & 5.63 & 24 & 9.38 & 0.1 \\
\hline $\begin{array}{l}\text { Speak with health } \\
\text { professionals }\end{array}$ & 7 & 23.33 & 64 & 21.25 & 0.4 \\
\hline
\end{tabular}

${ }^{*}$ Ignored or inconsistent data from 5 questionnaires.

Table 3 shows that the workshops had more than $65 \%$ of the students' approval, highlighting the workshop approval on sexually transmitted diseases. It is also noticeable that more than $8 \%$ of the adolescents did not fulfill the evaluation of the workshops. Among the respondents who were younger than 13 years, the puberty workshop was the best evaluated, although the adolescents of 13 years or more showed a preference for the workshop on Sexually Transmitted Diseases (non-tabulated data).

When comparing the different variables about those who liked or not the workshops, there was a statistically significant difference only with respect to the workshop "knowledge and puberty changes." Those who have not started sexual activity enjoyed in $79.22 \%$ of the cases, and those who already initiated sexual activity liked about $68.18 \%$ of the cases $(\mathrm{p}=0.03)$ (Table 4). The workshop "respect for the colleagues and other people's limits" was regarded as very good or excellent (favorable opinion) by $78.13 \%$ of women and $70.41 \%$ of men $(p=0.06)$, with no statistical significance. There was no difference in other variables (non-tabulated data). In this study, 90\% (n. 300) of the adolescents surveyed responded that they would like the project continued in the following year at their school, and $92.19 \%$ (n. 307) responded that they liked the medical students' work.

The directors or responsible people for the program, at the schools, entirely confirmed that the students became interested in the proposed topics. The medical students could answer 'the demands of schools/students that would like to continue with the project at their schools. In six of the eight schools, the person in charge considered that there was an improvement in knowledge about reproductive and sexual health by the students.

\section{Discussion}

The project about reproductive and sexual health included 1115 students. The signature to the consent and permission to participate in the research was only from $30 \%$ of the population. That is a challenge for researching with children and adolescents, especially, at the school environment [20]. That is because there are no definitions in relation to 
the autonomy and capability of adolescents to give their informed consent. Then, it is necessary the authorization and signature of a legal guardian in the Free and informed consent term, which hinders the inclusion of adolescents in the research [33].

Table 3. Distribution of schoolchildren according to their favorable opinion about the workshops.

\begin{tabular}{ccc}
\hline & $\mathrm{n}$ & $\%$ \\
\hline Self-esteem and respect for the body & 223 & 66.97 \\
Liked & 82 & 24.62 \\
Disliked & 28 & 8.41 \\
Did not answer/Did not initiate/Ignored & & \\
Knowledge and puberty changes & 232 & 69.67 \\
Liked & 70 & 21.02 \\
Disliked & 31 & 9.31 \\
Did not answer/Did not have/Ignored & & \\
Respect for colleagues and other people's limits & 225 & 67.57 \\
Liked & 79 & 23.72 \\
Disliked & 29 & 8.71 \\
Did not answer/Did not have/Ignored & & \\
Sexually Transmitted Diseases & 256 & 76.88 \\
Liked & 48 & 14.41 \\
Disliked & 29 & 8.71 \\
Contraceptive methods & & \\
Liked & 225 & 67.57 \\
Disliked & 75 & 22.52 \\
Did not answer/Did not have/Ignored & 33 & 9.91 \\
\hline
\end{tabular}

Table 4. Distribution of students according the favorable opinion about the workshops and the beginning of sexual activity.

\begin{tabular}{cccccc}
\hline & \multicolumn{2}{c}{$\begin{array}{c}\text { Initiated Sexual Activity } \\
(\mathrm{n}=71)\end{array}$} & \multicolumn{2}{c}{$\begin{array}{c}\text { Did not Initiate Sexual } \\
\text { Activity }(\mathrm{n}=256)\end{array}$} & $\mathrm{p}$ \\
\cline { 2 - 5 } & $\mathrm{n}$ & $\%$ & $\mathrm{n}$ & $\%$ & 0.1 \\
\hline $\begin{array}{c}\text { Self-esteem and } \\
\text { respect for the body } \\
\text { Knowledge and } \\
\text { puberty changes } \\
\text { Respect for the }\end{array}$ & 44 & 68.75 & 177 & 75.32 & 0.03 \\
$\begin{array}{c}\text { colleagues and other } \\
\text { people's limits } \\
\text { Sexually }\end{array}$ & 55 & 68.18 & 183 & 79.22 & 0.07 \\
$\begin{array}{c}\text { Transmitted Diseases } \\
\text { Contraceptive } \\
\text { methods }\end{array}$ & 38 & 85.94 & 167 & 71.37 & 0.4 \\
\hline
\end{tabular}


It was found a statistically significant difference with regard to the person they speak (and if they speak) about sexuality, among the youngsters that reported having started the sexual activity in comparison to those who did not start it. Those who did not begin the sexual activity speak with their parents or adults in a greater proportion than those who are sexually active. It can be inferred that the adolescents of this sample who got the informed consent from their parents to participate in the study are precisely those who have a greater closeness to the parents and/or legal responsible. Moreover, they are participative, educated and active in the formation of their children [22] [34]-[36].

A study conducted in São Paulo showed that parents were reported by approximately $20 \%$ of adolescents as a source of doubts clarification, regardless of the issue covered [37]. Another research performed in Toledo/PR reinforces the importance of good communication between parents and children because it was revealed that the embarrassment of some parents to talk about sexuality with their children is also assigned to the memories on how they were educated. Thus, these memories hinder the communication, transmission of knowledge and values related to sexuality of their children [38]. According to PeNSE, 2012, the National Survey of School Health, the adolescents who lived with their parents and had formal education tended to initiate their sexual activities later [8].

The sample obtained and analyzed showed that $13 \%$ of adolescents initiated the sexual activity before the age of 15 years. A much lower proportion than the studied in 2005 , in which $61.6 \%$ of youngsters of the Brazilian urban population interviewed had already begun the sexual life, and the mean age was 14.9 years [39]. The average age of the first sexual intercourse of youngsters living in the urban area of Pelotas was 15.7 years [40], and the residents of Concórdia 14.4 years [41]. PeNSE shows that approximately one fourth of the adolescents have already had sexual intercourse, and most frequently with the boys [8]. Among the adolescents who declared their sexual initiation, most of them had their first sexual relation at the age of 13 years or younger [8]. The early sexual activity produces unwanted consequences, and almost $21 \%$ did not use any protection the last time they had sex.

According to the sample, $40 \%$ of the students do not use condoms in any sexual activity. Other studies similarly show that although the use of condoms by the youngsters increased, it does not imply a continued use by them. Thereby, the use of condoms in the initiation determines its use in the last intercourse [42]. That datum also corroborates the information that there is a decrease in the use of condoms among young people, in southern Brazil, and also, they start earlier their sexual activities (before the age of 14) [39].

Researchers in Canada, France, Great Britain, Sweden and the United States have shown that the early sexual activity has little association with the income of the individual [43]-[45]. However, the young women who have little education are more likely to initiate the sexual activity during adolescence than those who are better educated [43]. Another study demonstrated that the youngsters who had up to four years of school presented a risk of $41 \%$ increase of early sexual initiation in comparison to those 
with 12 or more years of studies [40]. These data confront the current situation of early sexual initiation accompanied by the lack of information about sexuality showed by the youngsters of southern Brazil, where it is possible to assume a greater protection due to the bigger degree of local schooling [46].

In 2011, Brazil had 17.5 million of adolescents aged between 10 and 14 years (97.9\% of them were attending school), and other 17.0 million aged between 15 and 19 years (84.1\% attending school) [46]. Thus, it is pertinent that sex education needs to be a present subject since the beginning of school life. Then, it is going to be reached a larger number of adolescents in discussions about the issue and minimized the number of negative health effects related to the early sexual initiation [8] [40] [46]-[48].

The massive adoption from the students about reinforcing the activities for these subjects indicates the importance of sexual and preventive education, at the schools [3] [16]-[18] [47] [48]. The evaluation also demonstrates that the medical students' work, in the classroom, is a possible means of stimulating the implementation of programs on health promotion, which is essential for their training [27] [30]. Also, with the objective of promoting the reflection and spreading the discussion about doubts and insecurities on the subject, in the classroom environment [16]-[18] [28] [49] [50]. The interest shown by the workshops presented, especially for STD's, goes against the information that this subject is surrounded by fears, myths and taboos. That draws the adolescents' attention and points out their necessity of having knowledge on the topic, so that they can think over the real risks [51].

The workshops' assessment was different in relation to the age of the students because those with less than 13 years preferred the workshop on puberty, and those above 13 years presented greater interest in the workshop about sexually transmitted diseases. A study performed in Bahia in order to assess the level of knowledge on adolescence, puberty and sexuality, revealed that the fourth and fifth school years had 2.32 times of higher odds on poor information level compared to the sixth and eighth grades [52]. Therefore, many teenagers begin their sexual life without knowledge on those matters for which they have a curiosity [8] [36] [39] [40] [42] [52] [53]. Thus, the project joined to the early and gradual teaching, dealing with the children about issues such as changes brought on by puberty and adolescence, sexual initiation and hygiene aspects. After that, it is possible to transfer contents for the adolescents such as action and importance of contraceptive methods in the prevention of sexually transmitted diseases and family planning.

The obtained data support the need for considering the characteristics of the population served for the activities' planning [54]. Besides the already expected approval by the students that started the sexual activity in the workshops on STD and Contraceptive methods, it is possible to highlight the approval of the workshop "respect for colleagues and other people' limits." The activities to promote health on the reproductive rights must always consider the issue on sexual violence and its prevention, and that was the goal of this workshop.

In our experience we found that sex education was not being taught as a cross-cutting 
theme in any of the schools, and that any lessons were mostly dominated by a biomedical discourse focusing primarily on the reproductive organs, fertility, pregnancy, and contraception. Conducting workshops in a multidisciplinary manner, in the school environment, was considered the best way to discuss sexual issues with young people, by our group, because it is a friendly and welcoming environment that most adolescents, until 14 years old, still attend [8] [55]. Also, the school-based sex education is directly associated with a reduced risk on sexual behavior and sexually transmitted infections, in early adulthood, and the implementation of sexual health education, at the school, is considered as a source of empowerment for a young individual [56].

The medical students' main objective was a direct action, in the classroom, on the basis of continuous and permanent discussions during every week of the school year. The medical students went to the elementary schools and spent a period of adjustment and planning. They were seeking to know about the local reality, the most prominent vulnerabilities in the community, and also, they were trying to build a rapport with the school board and teachers.

Thus, the aim was to establish relationships of trust with the teenagers, and also, do not reproduce very common experiences when it comes to sexual education. In other words, giving very punctual and superficial lectures that do not make any sense for the students' needs or reality. Therefore, it was possible to draw a strategy in order to build pedagogical workshops in which the particular characteristics from each community on the island of Florianopolis were considered. Then, the experiences were built from the adolescents' interest, doubts or what they wanted to learn [56]. That way, one could avoid producing a standard material with the university vision on the disease prevention, and would perform the real action for health promotion, in the community [30] [57]. Then, the workshops were planned among the medical students, regular school teachers (from various subjects), school direction and supervised by professors from the college of medicine.

The present research presents some limitations, the main one is related to the sample because the only participants were those allowed by their parents. This is a cross-sectional study that evaluates the responses in a single point of their lives, without allowing the analysis of protection and risk factors. The questionnaires were self-administered and with inconsistency verification, however, without the possibility of checking the answers' accuracy answers, and only with quantitative and closed questions. The project results will only be assessable in the long term, with the analysis of health indicators from the population directly and indirectly affected by the project.

It is noteworthy that the project achieved positive results, the high approval by the students involved and the desire to continue the activities being performed. The project is going to continue for two more years, and some activities on health promotion, at the schools, are part of the curricula in the medical school.

Although the project included activities to the participation of teenagers' parents, their accession was scarce. Even so, it is important to encourage the communication between families and adolescent children [58], although it is often difficult and conten- 
tious. In this phase, the children need to receive information because if their parents do not provide it they will acquire from friends or in the streets, which contributes to the practice of unsafe sex and acquisition of misinformation [37] [38]. In 2016 part of the project activities are focused on participation and dialogue with parents of school.

The open dialogue with their children can be considered an enabling strategy in order to improve the communication process between adolescents and family [58] [59]. It might also be a time of feelings' reflection, to confront and set limits. Parents need to receive guidance about the type of communication they use with their children to talk about sexuality, taking into account the maturity and life stage of the adolescent. Thus, they are going to stimulate critical and reflective attitudes towards issues involving sexuality since, in that stage, there is apprehension of values that tend to remain for the rest of the person's life [37] [38] [60].

The teaching quality is one way of democratization, in the Brazilian society. Even small gains, if they are constant and continuous ones they will contribute to raising the education quality, in general. There is no way to think of an effective improvement, in the education quality of Brazil, without drastic changes on educational policies, which are expressed by the effective facilitation of better conditions in material, educational, personal and working aspects [6] [53].

The construction of joint projects among universities, government and school may extend the sexual education, in the elementary school, and include the students of the areas of health in activities on health promotion, in a community environment. Thus, it is possible to strengthen both the School Health Program [61] and the precepts of the National Curriculum Guidelines for the course of medicine [3] [15] The topic about sexuality initiates an inter-professional and transversal approach, encouraging the participation of the school and family in the orientation of Brazilian youngsters, working for a better reproductive and sexual health of the entire population [14] [39] [40].

\section{Conclusion}

There is no doubt that among children and adolescents who anticipated their sex life, especially from 11 to 12 years old, the misinformation risk is the most significant aspect to take into account to the establishment of programs for prevention of sexually transmitted diseases. Essentially, risky behaviors such as not using condoms or choosing multiple sexual partners without knowing that the majority of patients with sexually transmitted diseases such as herpes, for example, are completely asymptomatic, and the disease is completely invisible to their eyes. Thus, any preventive approach based on fear or clinical manifestations of any sexually transmitted disease will be completely unsuccessful for teens. Moreover, the authors also revealed that among youngsters who did not start their sexual life, the importance of previous dialogues with their parents may have had a decisive role. Then, such aspect should be taken into account when creating prevention strategies for youngsters, but now, with a new focus on parents or guardians. Therefore, developing frank dialogues with adolescents' families to face the social reality of early infection with HIV will improve the performance of institutions 
such as the university to act against a harsh reality with positive HIV youngsters at school. It is a faithful reflection of a new social context and the Brazilian public college has to face.

\section{Acknowledgements}

We wish to thank the Coordinator of the School Health Program, Giorgia Wiggers; the Ongoing Training Manager of the Municipal Secretary of Education, Gisele Pereira Jacques; the Principals and Teachers of the Primary Municipal Schools: Mâncio Costa, Osvaldo Machado, João Gonçalves Pinheiro, Henrique Veras, Donícia Maria da Costa, João Alfredo Rohr, Maria Conceição Nunes, Maria Tomázia Coelho, that contributed to the success of the program. This Program was supported by Ministry of Education, MEC Sesu Proext-2013 and MEC Sesu Proext-2014 and Proex UFSC-SUS 2015.

\section{Competing Interests}

The authors declare that they have no competing interests.

\section{References}

[1] Andrade, H.H.S.M., de Mello, M.B., et al. (2009) Changes in Sexual Behavior Following a Sex Education Program in Brazilian Public Schools. Cadernos de Saúde Pública, 25, 11681176. http://dx.doi.org/10.1590/S0102-311X2009000500023

[2] Figueiró, M.N.D. (1998) Revendo a história da educação sexual no Brasil: Ponto de partida para construção de um novo rumo. Nuances, 123-133.

[3] Brazil Parâmetros Curriculares Nacionais (1998) Terceiro e quarto ciclos: Apresentação dos temas transversais.

[4] Malta, D.C., Silva, M.A.I., et al. (2011) Sexual Health of Adolescents According to the National Survey of School Health. Revista Brasileira de Epidemiologia, 14, 147-156. http://dx.doi.org/10.1590/S1415-790X2011000500015

[5] Brazil Estatuto da Criança e do Adolescente. Lei federal No. 8.069 de 13 de julho, Diário Oficial da República Federativa do Brasil, Poder Executivo, Brasília, 1990.

[6] de Araujo Dias, M.S., Gomes, D.F., et al. (2014) School Health Program: Weaving an Analysis on Official Documents. SANARE-Revista de Políticas Públicas, 13.

[7] Currie, C.N.G.S., Roberts, C., et al. (2012) Health Policy for Children and Adolescents. WHO Regional Office for Europe, Copenhagen, 252.

[8] Brazil Pesquisa Nacional de Saúde do Escolar (PENSE). Instituto Brasileiro de Geografia e Estatística, Ministerio da Saúde, Rio de Janeiro, 2013.

[9] Ma, Z.Q., Fisher, M.A., et al. (2014) School-Based HIV/AIDS Education Is Associated with Reduced Risky Sexual Behaviors and Better Grades with Gender and Race/Ethnicity Differences. Health Education Research, 29, 330-339. http://dx.doi.org/10.1093/her/cyt110

[10] da Silva, D.R.Q., Guerra, O.U., et al. (2013) Sex Education in the Eyes of Primary School Teachers in Novo Hamburgo, Rio Grande do Sul, Brazil. Reproductive Health Matters, 21, 114-123. http://dx.doi.org/10.1016/S0968-8080(13)41692-0

[11] da Silva, D.R.Q. (2014) Sex Education in the Eyes of Brazilian Public School Teachers. Creative Education, 15, 1418-1427. http://dx.doi.org/10.4236/ce.2014.515160

[12] Parker, R.G. and Aggleton, P. (1999) Culture, Society and Sexuality: A Reader. Taylor \& 
Francis, London. http://dx.doi.org/10.4324/9780203212998

[13] Treichler, P.A. (1987) AIDS, Homophobia and Biomedical Discourse: An Epidemic of Signification. Cultural Studies, 1, 263-305. http://dx.doi.org/10.1080/09502388700490221

[14] Brazil Boletim Epidemiológico DSTs/AIDS. Ministerio da Saúde, Brasilia, 2014.

[15] Brazil Diretrizes curriculares nacionais dos cursos de graduação em enfermagem, medicina e nutrição. Ministério da Educação. Conselho Nacional de Educação, Brasilia, 2001.

[16] Flaherty, C. and Smith, P.B. (1981) Teacher Training for Sex Education. The Journal of School Health, 51, 261-264. http://dx.doi.org/10.1111/j.1746-1561.1981.tb02185.x

[17] McAndrew, S., Jackman, C. and Sisto, P.P. (2012) Medical Student-Developed Obesity Education Program Uses Modified Team-Based Learning to Motivate Adolescents. Medical Teacher, 34, 414-416. http://dx.doi.org/10.3109/0142159X.2012.668238

[18] Foster, K. and Laurent, R. (2013) How We Make Good Doctors into Good Teachers: A Short Course to Support Busy Clinicians to Improve Their Teaching Skills. Medical Teacher, 35, 4-7. http://dx.doi.org/10.3109/0142159X.2012.731098

[19] Hallock, J.A. (2001) Changing Emphases in Public Health and Medical Education in Health Care Reform. Towards Unity for Health, 3, 5-6.

[20] WHO (1986) Ottawa Charter for Health Promotion.

[21] Fawole, I.O., Asuzu, M.C., Oduntan S.O. and Brieger, W.R. (1999) A School-Based AIDS Education Programme for Secondary School Students in Nigeria: A Review of Effectiveness. Health Education Research, 14, 675-683. http://dx.doi.org/10.1093/her/14.5.675

[22] Camargo, E.A.I. and Ferrari, R.A.P. (2009) Adolescents: Knowledge about Sexuality before and after Participating in Prevention Workshops. Ciencia \& Saude Coletiva, 14, 937-946. http://dx.doi.org/10.1590/S1413-81232009000300030

[23] Díaz, M., de Mello, M.B., et al. (2005) Outcomes of Three Different Models for Sex Education and Citizenship Programs Concerning Knowledge, Attitudes, and Behavior of Brazilian Adolescents. Cadernos de Saúde Pública, 21, 589-597. http://dx.doi.org/10.1590/S0102-311X2005000200026

[24] Swain, R. and McNamara, M. (1997) The Effects of a Participative Programme on Irish Pupils' Attitudes to HIV/AIDS. Health Education Research, 12, 267-273. http://dx.doi.org/10.1093/her/12.2.267

[25] Meyer, D.E.E., Klein, C., Klein, C. and Andrade, S.S. (2007) Sexuality, Pleasures and Vulnerabilities: Educational Implications. Educação em Revista, 46, 219-239. http://dx.doi.org/10.1590/S0102-46982007000200009

[26] Main, D.S., Iverson, D.C., et al. (1994) Preventing HIV Infection among Adolescents: Evaluation of a School-Based Education Program. Preventive Medicine, 23, 409-417. http://dx.doi.org/10.1006/pmed.1994.1056

[27] Duclós, L.C., Vilela, T.F., et al. (2014) Educational Actions for Sexual Health Promotion: Discussion on the Role of Local Health Units in the Municipality of Florianopolis. 2014 Annual Conference of the Network toward Unity for Health, Fortaleza, 19-23 November 2014.

[28] Dennis, K.J. and Elstein, M. (1980) Education in Sexuality in the Medical Curriculum. Clinics in Obstetrics and Gynaecology, 7, 183-191.

[29] Lima, M.C.P. and Cerqueira, A.T.A.R. (2008) Beliefs about Sexuality among Medical Students: A Comparison between Gender. Revista Brasileira de Educação Médica, 32, 49-55. http://dx.doi.org/10.1590/S0100-55022008000100007 
[30] Cofre, J., Knobel, R., et al. (2014) School-Based Sex Education Program: A Multidisciplinary Experience Induced by Medicine Students. 3rd International Congress Sexuality and Sexual Education, Lisbon, 10-12 July 2014.

[31] Aggleton, P. (1991) Young People, HIV/AIDS and Social Research. AIDS Care, 4, 243-244. http://dx.doi.org/10.1080/09540129208253096

[32] Ues, B., Knobel, R., et al. (2013) Utilização da disciplina de Educação Física na abordagem da sexualidade de jovens nas escolas municipais de Florianópolis: Uma experiência na formação de profissionais médicos. 31 st SEURS Seminário de Extensão Universitária da Região Sul, Florianópolis, 4-7 August 2013.

[33] Guariglia, F., Bento, S.F. and Hardy, E. (2006) Adolescents as Research Subjects and Free Informed Consent: Knowledge and Opinion of Researchers and Adolescents. Cadernos de Saúde Pública, 22, 53-62. http://dx.doi.org/10.1590/S0102-311X2006000100006

[34] Maldonato, M.T. (1981) Comunicação entre pais e filhos: a linguagem do sentir. Ed Vozes, Petrópolis.

[35] Costa, M.R.P.S. (2002) Adolescência: Aspectos clínicos e psicossociais. Artmed Editora, São Paulo.

[36] Gonzalez, A.E., Molina, G.T., Adela, M.V. and Vania, M.N. (2013) [Factors Associated with Early Sexual Activity among Chilean Adolescents]. Revistoa Médica de Chile, 141, 313-319. http://dx.doi.org/10.4067/S0034-98872013000300005

[37] Borges, A.L.V., Nichiata, L.Y.I., et al. (2006) Talking about Sex: The Social and Familial Net as a Base for Sexual and Reproductive Health Promotion among Adolescents. Revista Latino-Americana de Enfermagem, 14, 422-427.

[38] Almeida, A.C.C.H. and Centa, M.L. (2009) Parents Experience with the Sexual Education of Their Children: Implications for Nursing Care. Acta Paulista de Enfermagem, 22, 71-76.

[39] Paiva, V., Calazans, G., et al. (2008) [Age and Condom Use at First Sexual Intercourse of Brazilian Adolescents]. Revista de Saúde Pública, 42, 45-53. http://dx.doi.org/10.1590/S0034-89102008000800007

[40] Hugo, T.D., Maier, V.T., et al. (2011) [Factors Associated with Age at First Intercourse: A Population-Based Study]. Cadernos de Saúde Pública, 27, 2207-2214. http://dx.doi.org/10.1590/S0102-311X2011001100014

[41] Gubert, D. and Madureira, V.S. (2008) [The Onset of Sexual Activity in Male Adolescents]. Ciência \& Saúde Coletiva, 13, 2247-2256. http://dx.doi.org/10.1590/S1413-81232008000900029

[42] Teixeira, A.M.F.B., Knauth, D.R., et al. (2006) Teenagers and Condom Use: Choices by Young Brazilians from Three Brazilian State Capitals in Their First and Last Sexual Intercourse. Cadernos de Saúde Pública, 22, 1385-1396. http://dx.doi.org/10.1590/S0102-311X2006000700004

[43] Singh, S., Darroch, J.E. and Frost, J.J. (2001) Socioeconomic Disadvantage and Adolescent Women's Sexual and Reproductive Behavior: The Case of Five Developed Countries. Family Planning Perspectives, 33, 251-258, 289. http://dx.doi.org/10.2307/3030192

[44] Blum, R.W., Beuhring, T., Shew, M.L., Bearinger, L.H., Sieving, R.E. and Resnick, M.D. (2000) The Effects of Race/Ethnicity, Income, and Family Structure on Adolescent Risk Behaviors. American Journal of Public Health, 90, 1879-1884. http://dx.doi.org/10.2105/AJPH.90.12.1879

[45] Whitbeck, L.B., Yoder, K.A. Hoyt, D.R. and Conger, R.D. (1999) Early Adolescent Sexual Activity: A Developmental Study. Journal of Marriage and the Family, 61, 934-946. http://dx.doi.org/10.2307/354014 
[46] IBGE (2012) Pesquisa Nacional por Amostra de Domicílios: síntese de indicadores. Ministério do Planejamento, Orçamento e Gestão, Rio de Janeiro.

[47] Beatty, B.G., O’Connell, M., Ashikaga, T. and Cooper, K. (2003) Human Papillomavirus (HPV) Education in Middle and High Schools of Vermont. Journal of School Health, 73, 253-257. http://dx.doi.org/10.1111/j.1746-1561.2003.tb06573.x

[48] Kohler, P.K., Manhart, L.E. and Lafferty, W.E. (2008) Abstinence-Only and Comprehensive Sex Education and the Initiation of Sexual Activity and Teen Pregnancy. Journal of Adolescent Health, 42, 344-351. http://dx.doi.org/10.1016/j.jadohealth.2007.08.026

[49] Ues, B., Cofre, J., et al. (2013) Aprendendo juntos sobre sexualidade-alunos de medicina inseridos no programa saúde na escola. 51 st Congresso Brasileiro de Educação Médica, Olinda, 19-22 October.

[50] Ues, B., Knobel, R., et al. (2014) Ajuda mútua entre estudantes de medicina e escolares do $8^{\circ}$ ano primário para construir um programa de sexualidade saudável nas escolas públicas de Florianópolis. 11 st Congresso Internacional da Rede Unida, Fortaleza, 10-13 April 2014.

[51] Camilo, V.M.B., Freitas, F.L.S., et al. (2009) Educação em saúde sobre DST/AIDS com adolescentes de uma escola pública, utilizando a tecnologia educacional como instrumento. DST_Jornal Brasileiro de Doenças Sexualmente Transmissiveis, 21, 124-128.

[52] Gomes, W.A., Costa, M.C.O., et al. (2002) Adolescents' Knowledge about Adolescence, Puberty and Sexuality. Jornal de pediatria, 78, 301-308. http://dx.doi.org/10.2223/jped.864

[53] Bueno, J.G.S. (2001) Função social da escola e organização do trabalho pedagógico. Educar em Revista, 17, 101-110. http://dx.doi.org/10.1590/0104-4060.222

[54] Aggleton, P. and Kapila, M. (1992) Young People, HIV/AIDS and the Promotion of Sexual Health. Health Promotion International, 7, 45-51. http://dx.doi.org/10.1093/heapro/7.1.45

[55] Vivancos, R., Abubakar, I., Phillips-Howard, P. and Hunter, P.R. (2013) School-Based Sex Education Is Associated with Reduced Risky Sexual Behaviour and Sexually Transmitted Infections in Young Adults. Public Health, 127, 53-57. http://dx.doi.org/10.1016/j.puhe.2012.09.016

[56] Oliveira-Campos, M., Giatti, L., Malta, D. And Barreto, S.M. (2013) Contextual Factors Associated with Sexual Behavior among Brazilian Adolescents. Annals of Epidemiology, 23, 629-635. http://dx.doi.org/10.1016/j.annepidem.2013.03.009

[57] Kraft, J.M., Kulkarni, A., Hsia, J., Jamieson, D.J. and Warner, L. (2012) Sex Education and Adolescent Sexual Behavior: Do Community Characteristics Matter? Contraception, 86, 276-280. http://dx.doi.org/10.1016/j.contraception.2012.01.004

[58] Davis, E.C. and Friel, L.V. (2001) Adolescent Sexuality: Disentangling the Effects of Family Structure and Family Context. Journal of Marriage and Family, 63, 669-681. http://dx.doi.org/10.1111/j.1741-3737.2001.00669.x

[59] Moore, K.A., Peterson, J.L. and Furstenberg, F.F. (1986) Parental Attitudes and the Occurrence of Early Sexual Activity. Journal of Marriage and the Family, 48, 777-782. http://dx.doi.org/10.2307/352570

[60] Thomé, C.L. and Hensel, D. (2011) Relatos de percepções e sentimentos de pais e filhos sobre iniciação sexual. Unoesc \& Ciência-ACHS, 2, 81-88.

[61] Brazil (2007) Decreto No 6.286, de 5 de Dezembro De 2007. Institui o Programa de Saúde na Escola-PSE, e da outras providencias. Diário Oficial da República Federativa do Brasil, Poder Executivo, Brasília. 
Submit or recommend next manuscript to SCIRP and we will provide best service for you:

Accepting pre-submission inquiries through Email, Facebook, LinkedIn, Twitter, etc. A wide selection of journals (inclusive of 9 subjects, more than 200 journals)

Providing 24-hour high-quality service

User-friendly online submission system

Fair and swift peer-review system

Efficient typesetting and proofreading procedure

Display of the result of downloads and visits, as well as the number of cited articles

Maximum dissemination of your research work

Submit your manuscript at: http://papersubmission.scirp.org/

Or contact jss@scirp.org 